\title{
LUT
}

University

\section{A Dynamic Learning Perspective on Innovation Control: Balancing Freedom and Constraint}

Saunila Minna, Mäkimattila Martti

This is a Author's accepted manuscript (AAM) version of a publication

published by Palgrave Macmillan, Cham

in Innovation and Capacity Building. Palgrave Studies in Cross-disciplinary Business Research, In Association with EuroMed Academy of Business.

DOI: 10.1007/978-3-319-90945-5_14

Copyright of the original publication: (C) The Author(s) 2018

Please cite the publication as follows:

Saunila, M., Mäkimattila, M. (2018). A Dynamic Learning Perspective on Innovation Control:

Balancing Freedom and Constraint. In: Vrontis D., Weber Y., Thrassou A., Shams S., Tsoukatos

E. (eds) Innovation and Capacity Building. Palgrave Studies in Cross-disciplinary Business

Research, In Association with EuroMed Academy of Business. Palgrave Macmillan, Cham. DOI: 10.1007/978-3-319-90945-5_14

This is a parallel published version of an original publication.

This version can differ from the original published article. 


\title{
A dynamic learning perspective on innovation control: Balancing freedom and constraint
}

\author{
Minna Saunila \\ D.Sc. (Tech.), Senior researcher \\ Lappeenranta University of Technology, Saimaankatu 11, 15140 Lahti, Finland \\ Martti Mäkimattila \\ D.Sc. (Tech.), Manager, Green Campus Open Accelerator \\ Lahti University of Applied Sciences, Niemenkatu 73, 15140 Lahti, Finland
}

1. Introduction

In order to translate innovation capability into successful results via products, technologies, services, or business models, firms require innovation control. In other words, companies need to manage and measure their innovation capability and related processes in an active and resultoriented way (Adams, Bessant \& Phelps, 2006). Clearly defined goals and control mechanisms for timing, resources, and quality are essential. Innovation control can help organisations define what resources (in terms of quantity, type, and personnel capabilities) are needed to implement each action.

Recent innovation research has complemented perspectives related to individuals and their environments, which feature both group and organisational aspects. The shift in the focus of innovation studies underlines an important stream of research on innovation control systems. As work occurs within companies, individuals' surroundings are largely affected by control mechanisms (Davila, Foster \& Oyon, 2009). The application of innovation control is frequently depicted by a strong ambidexterity between the strong use of measurement mechanisms and significant amounts of freedom in order to enhance creativity. Thus, organisational-level innovation control seems to be an auspicious research area that should concentrate on both the 
individual and collective processes, with organisational needs in mind (Saunila, 2017). These three levels of analysis (i.e., individual, group, and organisational) are extensively represented in the literature on innovation and learning (see James, Guile \& Unwin, 2013). However, little is known about the ways in which management actions advance these three levels of innovation control in practice. In order to flourish, the controlling processes should be able to balance between the rival forces of freedom and constraint (see Simons, 2000). Research in innovation is also moving towards a better understanding of innovations as a managed and controlled process (Chebbi, Yahiaoui \& Thrassou., 2017; Davila et al., 2009; Janssen, Moeller \& Schlaefke, 2011; Saunila, Ukko \& Rantanen, 2014).

However, the existing conceptualisations of innovation control actions remain limited and have not addressed the different dimensions related to dynamic processes. This study examines the combination of and control over innovation resources, at both individual and team levels, that are used to achieve organisational goals. Individual interests and organisational capabilities are analysed during a reformation of the innovation process and organisational structures of a media company. This study could be beneficial to those who are attempting to make sense from the complex context of innovating daily content and building multichannel platforms to create businesses for the future. We believe that innovation control discussions could be enriched by applying approaches from a dialectic perspective and by presenting them in an organisational learning context. Furthermore, describing different types of controls and observation levels during the innovation process (e.g., James et al., 2013; Saunila, 2017) might help us understand the cognitive and dialectic dimensions when addressing personal and managerial characteristics in accordance with situational demands (Bledow, Frese, Anderson, Erez \& Farr, 2009a, 2009b).

In this chapter, we note the challenge of developing innovations as outcomes requiring exploration and exploitation on multiple levels of organising. Enabling individuals, teams, and organisations to participate efficiently in innovation activities requires control of resources. In addition, recent literature suggests that management control systems influence innovation (cf. Henri, 2006; Franco-Santos, Lucianetti \& Bourne, 2012; Saunila, 2017) but does not specify how 
control mechanisms inform and assist innovation. In the following text, we continue the earlier discussion on dialectic perspectives with respect to innovation (see Bledow et al., 2009a, 2009b) and innovation control (see Davila et al., 2009; Haustein, Luther \& Schuster, 2014) while stressing the need for a multilevel approach to controls. The research question is, "How does innovation control integrate with innovation as a multilevel process?"

The chapter is structured as follows: The literature review introduces the theories of innovation and management control, after which a case study using several research methods is presented. This chapter also discusses control mechanisms that operate on multiple levels of an organisation to drive innovation. We describe the dynamics of the innovation process, which requires various controls to refine ideas devised through innovation. Finally, theoretical conclusions and some managerial suggestions for flexible control and developing processes that aim to build an innovative organisation are presented.

\section{Literature Review}

\subsection{Dialectic approach to innovation as a multilevel dynamic process}

The dialectic perspective on innovation focuses on the dynamics of intentional development and on the introduction of useful new ideas (Bledow et al., 2009a). Innovations include creative ideas and their implementation in the forms of products, processes, services, and organisational innovations (Schumpeter, 1934; Tidd, Bessant \& Pavitt, 2005). Following the dialectic approach (Bledow et al., 2009a, 2009b) based on previous work by March (1991), it is seen that in the contexts of knowledge and learning, exploration includes terms such as search, variation, risktaking, experimentation, flexibility, and discovery. Exploitation refers to concepts including production, selection, implementation, and execution. The different characteristics of various phases of innovation as knowledge-based processes can be identified (Chebbi et al., 2017; Chesbrough, 2003; Tidd et al., 2005). Recent discussion has highlighted the idea that innovation is more of a dynamic complementary process with integrated feedback loops than a linear set of pre-planned steps to final outcomes (cf. James et al., 2013; Mäkimattila, 2014; Mäkimattila, Melkas \& Uotila, 2013; Santoro, Vrontis, Thrassou \& Dezi, 2017; Thrassou, Vrontis \& Bresciani, 2018a, 2018b): Actions at different levels need to be synchronised. Although grounded in the 
tasks of individuals, the group initiative is to handle uncertainty related to the tasks and to entrust challenging demands to group processes (Brav, Andersson \& Lantz, 2009). Individuals, teams, and organisations need to manage conflicting demands and to self-regulate and control issues via alternative pathways that lead from ideas to innovations.

According to Bledow et al. (2009a, 2009b), the core point of the dialectic approach is the integration of complementary and even opposite cognitions, emotions, and activities for facilitating successful innovation. The variety of interests and temporal challenges leads to one of the key issues: how individuals, teams, and organisations can control conflicting processes. Bledow et al. (2009a, 2009b) pointed out that shifting between several alternatives and integrating them is more likely to result in new solutions than committing to a single alternative in the early phase. The dialectic approach emphasises the idea that a problem representation is not a static cognitive structure but rather a constant, constructive process that synthesises previous problem representations with novel information (Bledow et al., 2009a, 2009b). Based on the dialectic perspective, Bledow et al. (2009a, 2009b) state that in practice, there is no easy way to manage innovation or to separate exploration and exploitation during innovation processes. Managers should instead be flexible in their approach to complementary activities and, depending on the situation, move from aims related to enforcing a particular structure to keeping complementary actions open to exploration. The flexibility to shift between structuring and opening processes is important to the different demands that surface during the innovation process (Bledow et al., 2009a, 2009b; Mäkimattila, 2014; Vrontis, Thrassou, Chebbi \& Yahiaoui, 2012).

Bledow et al. (2009a, 2009b) discussed and presented innovation demands and activities with embedded tensions at different levels within organisations. The authors described challenges at individual, team and, organisational levels when exploring and exploiting innovation, for example, by presenting ambidexterity from the regulation of explorative and exploitative actions on multiple organisational levels. Mäkimattila (2014) and Fjeldstad, Snow, Miles and Lettl (2012) related similar findings concerning management structures and self-organisation as well as motivation and situational awareness but focused more on intra-organisational aspects related to enabling inter-organisational collaboration for innovation. Prajogo and Ahmed (2006) found that 
organisations need to enhance certain behavioural and cultural practices to achieve high innovation performance. Only within these ancillary environments is it possible for organisations to enhance their potential for more effectively working to attain desired outcomes and high performance in the area of innovation. Empirical studies have shown that highly innovative firms have slack structures in the front-end phase of the innovation process and develop more formal controls and structures in the back-end stages of the innovation process (Van der Panne, Van Beers \& Kleinknecht, 2003).

\subsection{Controls for innovation}

Since control aims to ensure the achievement of an entity's purpose, plans, and targets, control at an organisational level can be said to encompass the processes in which someone deliberately influences what another individual, group, or organisation will do (Tannenbaum, 1968). Furthermore, prior research has pointed out the interactive relationship between management control and organisational behaviour. Researchers have suggested that the application of control mechanisms is a social phenomenon, as behaviour mediated by these mechanisms is shaped by the feelings, values, and basic beliefs of the individuals and the organisation, as well as the community and society within which the organisation operates (Franco \& Bourne, 2003; Nudurupati \& Bititci, 2005). This notion is also applicable to the idea of innovation as a process. Many authors have concluded that in today's world, innovation is best understood as a largely repetitive process that can be managed and thus requires particular attention to the design of management control (e.g., Davila et al., 2009; Haustein et al., 2014; Janssen et al., 2011). According to Davila et al. (2009, p. 285), innovation is "about taking advantage of exceptions; experimenting, failing and succeeding; uncertainty and volatility; inefficiencies; adapting to unforeseen opportunities; and foremost creativity.” These types of processes, such as specifying an idea that becomes the foundation of a new firm or a new service, require motivational surroundings. Control processes, such as goal-setting, performance measurement, and reward systems, are important in shaping this environment (Davila et al., 2009). In particular, when referring to innovation as a process, the need exists for a relevant control system to manage it. Where the only formal control mechanism is to choose between go/no-go decisions, managers 
are only able to hope that internal controls in the department (or "clan control") can lead to successful outputs. This structure has proven to be limited and useful only for basic research activities (Davila et al., 2009).

Based on previous studies (Franco-Santos et al., 2012; Henri, 2006), indirect and interactively used control mechanisms and performance measurements can benefit innovation. According to Revellino and Mouritsen (2009), innovation has to undergo a number of phases and activities, each of which calls for different controls that mediate between the innovation and its environment. Control systems can be divided based on the style of use; some examples of contrasting styles include organic or mechanistic (cf. Chenhall, 2003), interactive or diagnostic (cf. Simons, 2000), and direct or indirect (cf. Hutzschenreuter, 2009). The division is usually dasignated based on the degree of interplay with personnel. Interactive systems enhance the dialogue and knowledge exchange based on presumptions. The aim of these systems is to enhance idea development, but they do not impact other aspects of the innovation process (Davila et al., 2009). Labitzke, Svoboda and Schultz (2014) demonstrated the positive influence of informal controls on innovation activity, but with respect to formal controls, no significant effect on innovation activity has been noted. Ylinen and Gullkvist (2014) found organic forms of control to increase project performance in both exploratory and exploitative innovation. Radical innovation, especially in the early stages of development, is characterised by a strong dependence on flexible and social controls, whereas diagnostic control occurs mainly in late development and commercialisation (Chiesa, Frattini, Lamberti \& Noci, 2009).

Recent studies have revealed that to foster innovation, multiple control mechanisms should be implemented simultaneously. There is still little systematic evidence as to how control mechanisms inform and assist innovation and how the effects of one form of control are complementary to and simultaneously rely on another form of control (Malmi \& Brown, 2008). The framework of Merchant and Van der Stede (2012) was selected as a reference for this study because it regards results and action controls as typically administrative and more direct types of control but includes also more indirect types of controls. These include personnel control, which enables employees to control and motivate themselves, and cultural control, which encourages 
mutual monitoring. Instead of personnel control, idea control and resource control are used to represent the indirect controls. However, personnel are involved in all control mechanisms. We chose this division of controls because it is not limited to a certain industry, organisation size, or set of business characteristics.

\section{Research Methodology}

The study results were derived from case study research. Due to the exploratory nature of the research, the case study method was considered appropriate, given the lack of existing theory combined with the importance of the phenomenon in practice. Accordingly, the guidelines of abductive reasoning were adopted in conducting the research. According to Kovács and Spens (2005), this approach seeks to develop theories by concentrating on interpreting and understanding a phenomenon that has not yet been researched.

Data were collected from a Finnish company associated with multiple areas of media business. The case company includes many units and departments that have distinct roles and responsibilities in the organisation, with some common and some discrete functions. The case company offers a variety of services; for example, it publishes several newspapers, operates a radio channel, and offers web-based services. In addition to main business units, the support functions include distribution and printing as well as administrative and IT departments. The case company employs approximately 270 workers and faces fierce competition caused by the shift from traditional to new media, while struggling with the urge to cope with a rapidly changing operating environment. Nowadays, cost-cutting is not a solution for success and profits, and the case company realises that innovations are required to renew and to ensure future performance. An innovation process has been developed for the company via a digital idea-collection system, but the system did not fulfil its expectations and was therefore not adequately used. There were problems in the encouragement of positive interaction in idea development and implementation because some of the business units were also each other's competitors. In a 2-year research period, collaborative actions were undertaken to frame the innovation process from idea to innovation and to determine the types of organisational preparation needed to better utilise external 
innovation. In such a dynamic context, a company needs control to manage innovation and to clarify how innovation control integrates innovation proceeding at different levels.

Table 14.1. Data used to examine innovation control in a case company

\begin{tabular}{|c|c|c|c|}
\hline Purpose & Data & $\begin{array}{l}\text { Number of } \\
\text { people involved }\end{array}$ & Output \\
\hline $\begin{array}{l}\text { To clarify the state of } \\
\text { innovation activities and future } \\
\text { needs }\end{array}$ & Interviews & $\begin{array}{l}15 \text { senior } \\
\text { managers and } \\
\text { innovation } \\
\text { agents }\end{array}$ & $\begin{array}{l}\text { Prerequisites of the } \\
\text { successful innovation } \\
\text { process }\end{array}$ \\
\hline $\begin{array}{l}\text { To clarify the output of the } \\
\text { interviews }\end{array}$ & $\begin{array}{l}\text { Group } \\
\text { interviews }\end{array}$ & $\begin{array}{l}15 \text { senior } \\
\text { managers and } \\
\text { innovation } \\
\text { agents }\end{array}$ & $\begin{array}{l}\text { Development targets } \\
\text { of the innovation } \\
\text { process and related } \\
\text { activities }\end{array}$ \\
\hline $\begin{array}{l}\text { To create the control } \\
\text { mechanisms of the innovation } \\
\text { process }\end{array}$ & Development & $\begin{array}{l}\text { 3-6 innovation } \\
\text { agents } \\
2-4 \text { researchers }\end{array}$ & $\begin{array}{l}\text { Description of the } \\
\text { innovation process } \\
\text { and control } \\
\text { mechanisms } \\
\text { (manageable self- } \\
\text { organisation) }\end{array}$ \\
\hline $\begin{array}{l}\text { To form a common } \\
\text { understanding of the results } \\
\text { and benefits of the completed } \\
\text { process }\end{array}$ & $\begin{array}{l}\text { Final } \\
\text { interviews }\end{array}$ & $\begin{array}{l}6 \text { innovation } \\
\text { agents }\end{array}$ & $\begin{array}{l}\text { Elements functioning } \\
\text { well in the current } \\
\text { innovation control } \\
\text { system and } \\
\text { development of future } \\
\text { targets }\end{array}$ \\
\hline
\end{tabular}

A single case was chosen to get valuable in-depth information about innovation control under a condition of change and organisational readjustment. Multiple sources of data were utilised, and several researchers were involved to obtain triangulation and to ensure valid and reliable results (Eisenhard, 1989; Flyvbjerg, 2006; Pålshaugen, 2009; Voss, Tsikriktsis \& Frohlich, 2002; Yin, 1994). The research process included four prior phases of data collection and was performed concurrently with the organisation's strategic development process. Collecting different types of 
data allowed for data triangulation (see Table 14.1). The data included written works by the case company's employees as well as taped and transcribed interviews. Interview questions were openended and planned in advance, but the discussions were unofficial and allowed researchers to present further questions. Two researchers simultaneously analysed the data by content analysis and engaged in discussions for the purpose of forming a common understanding. At this time, theory triangulation was adopted. The goal of this process was to employ different theoretical frameworks for introducing new concepts. Although the study originates from management control research, innovation management and organisational learning research were also used to integrate the existing theory with new contexts.

\section{Results}

Organisational management has different expectations and needs when it comes to innovation control. Many interviewees maintained that decisions to shift from structuring a given situation to keeping it free and open to exploration should be made based on the innovation process's phase and situation. With respect to the case organisation, it is crucial that routine evaluations be made at each level to avoid management delays and to ensure that workers will not feel pressured to take unofficial actions. . One undesirable phenomenon, seemingly with ease, is the tendency to bring every issue to the top level of an organisation. The decision-making mechanisms must fit the needs of the organisation without causing inertia or time delays.

In the case organisation, the employees responsible for innovation activities clarified the challenge faced by the company: It is easy to place emphasis on only those actions that are visible, which makes it easier to cut other efforts rather than controlling them and targeting them to organisational goals. The employees recognised that the organisation should also exploit resources in the early phases of the innovation process and have the buoyancy to combine different control mechanisms. The challenge is to let an organisation adjust organically based on the innovation. These challenges should be met simultaneously to ensure the functioning of daily operational activities that create company revenue with which to finance ideas and innovations and thus will translate into future success stories. Based on the process employed in the case 
company, if the organisation is focused only on operations and existing products and/or services, the incremental innovations developed are predominately related to these current products and processes. In this case of incremental improvements, the emphasis of the innovation process is on the late phases and direct control mechanisms. If the organisation is adapting more radical innovations, the role of indirect control in the early phases is pronounced.

The complexity of the control mechanisms becomes clear when considering which individuals are needed to take part in the organisation's decision making. In this case study, it was apparent that the decision-making paths were ambiguous and required clarification. The general practice was that to push ideas forward, employees were required to talk to managers, who had the authority to make decisions. In the case company, decision making was distributed among different management groups, and orders given were perceived to be only partially optimal rather than conveying complete agreement with a proposed concept. The result was that employees were trying to perform daily tasks without benefiting from the input of different levels within the organisation.

Based on the interviews, individuals with different knowledge bases and backgrounds may create the most fruitful ideas. Initially, creative individuals develop an idea whenthe opportunity to address a particular need is clear. After this initial spark, the idea is elevated to the team level, where it is supplemented with additional ideas. At an organisational level, it is linked with other teams' perspectives in such a way that individuals connect things to their own challenges related to the innovation process. The idea is additionally linked at that time to the company's strategy. When the innovation is complemented, it will return to the original point of departure (to the individuals who will apply it to the realised operating environment. This requires a variety and mixture of controls at different stages.

Choosing the right ideas and managing activities related to these ideas at the right levels requires an understanding of the process of exploring complementary ideas and then exploiting them at both the group and organisational levels. The interviewees stated that the loops that link the individuals having ideas to group-level refinement and organisational interest before returning to the individual level of complementary ideas must be fully realised. This is not usually visible 
through direct action and result control mechanisms. In the case company, the management of exploration and exploitation, as well as shifting between the competing processes of convergent and divergent thinking during the innovation process, was overcome by forming an innovation agent group - a group of individuals to provide the prerequisites for idea development and to align innovations for strategy and to support management in innovation activities. Allowing individuals from different functions and job descriptions to further innovation processes, including connections with management for total business optimisation, was seen as a proper solution for innovation control. Such an innovation agent group combined individuals and their processes, namely development of the innovation process, the fostering and generation of new ideas, and the selection and transformation of these ideas into successful innovations. In contrast, the traditional approach refined ideas within one's own unit and department.

Also in the case company, prior attempts were made to solve management problems related to the innovation process by collecting ideas for the IT system, but this strategy failed and was attributable to a lack of control mechanisms for fostering an interactive "debate platform" where innovation could be complemented. Resources had been used within units to promote innovation because a common arena for dialogue was missing. Due to the new agent solution, which included the development of a group that supported innovation outside the boundaries of the organisation's operational units, a dialectic was achieved through which the implementation and application of indirect control mechanisms took place in a different way. Agents encouraged interaction and built a common understanding regarding innovation activities. Management supported this. The group also catalysed and supported the innovation process, forming a connective platform across units in the organisation. Such a group within an organisation selects the ideas for further development and guides the process of implementation. The development of the new group was a reflection of innovation control. The agents' role was to ensure the resources and progress of innovation development. They also built link innovations to strategy and support management. The results are summarised in Table 14.2. 
Table 14.2. Innovation control in different phases

\begin{tabular}{|c|c|c|}
\hline $\begin{array}{l}\text { Phase of } \\
\text { innovation process }\end{array}$ & Outcomes from dialectic perspective & $\begin{array}{l}\text { Focus on control } \\
\text { characteristic }\end{array}$ \\
\hline $\begin{array}{l}\text { Signals and } \\
\text { opportunity } \\
\text { recognition }\end{array}$ & $\begin{array}{l}\text { Interaction platforms and organisational culture- } \\
\text { everyone's job includes acquiring and sharing } \\
\text { cross-functional information. }\end{array}$ & $\begin{array}{l}\text { Cultural control, } \\
\text { exploration }\end{array}$ \\
\hline Idea generation & $\begin{array}{l}\text { A platform to integrate ideas from different } \\
\text { departments; culture that supports this supportive }\end{array}$ & $\begin{array}{l}\text { Idea control, } \\
\text { exploration }\end{array}$ \\
\hline Idea evaluation & $\begin{array}{l}\text { Systematically conduct evaluation in cross- } \\
\text { functional teams and link to organisational } \\
\text { strategy. }\end{array}$ & $\begin{array}{l}\text { Idea control, } \\
\text { exploration }\end{array}$ \\
\hline Refining concepts & $\begin{array}{l}\text { Products and services create value for the } \\
\text { user/customer; organisation of platforms for } \\
\text { refining and connecting individual cognitive } \\
\text { processes to add new ideas in the dialectic } \\
\text { process. }\end{array}$ & $\begin{array}{l}\text { Idea control, } \\
\text { exploration, and } \\
\text { exploitation }\end{array}$ \\
\hline $\begin{array}{l}\text { Decision to develop } \\
\text { further }\end{array}$ & $\begin{array}{l}\text { A common view between different departments } \\
\text { on how to proceed with innovation is achieved. }\end{array}$ & $\begin{array}{l}\text { Resource control, } \\
\text { exploitation }\end{array}$ \\
\hline Starting project & $\begin{array}{l}\text { As soon as possible by assessing profitability in } \\
\text { terms of internal or external resources, costs, etc. }\end{array}$ & $\begin{array}{l}\text { Action control, } \\
\text { exploitation }\end{array}$ \\
\hline $\begin{array}{l}\text { Running R\&D } \\
\text { project }\end{array}$ & $\begin{array}{l}\text { Clearly lead process by utilising internal and } \\
\text { external resources. }\end{array}$ & $\begin{array}{l}\text { Action control, } \\
\text { exploitation }\end{array}$ \\
\hline Testing & Gather user/customer feedback for all levels. & $\begin{array}{l}\text { Results control, } \\
\text { exploitation }\end{array}$ \\
\hline Implementing & $\begin{array}{l}\text { Implementation internally communicated before } \\
\text { external actions }\end{array}$ & $\begin{array}{l}\text { Results control, } \\
\text { exploitation }\end{array}$ \\
\hline $\begin{array}{l}\text { Measuring } \\
\text { innovation process }\end{array}$ & Define measures that cover the whole process. & $\begin{array}{l}\text { Results control, } \\
\text { exploitation }\end{array}$ \\
\hline Learning & $\begin{array}{l}\text { Individuals enable learning throughout the } \\
\text { organisation. }\end{array}$ & $\begin{array}{l}\text { Results control, } \\
\text { exploitation }\end{array}$ \\
\hline
\end{tabular}

\section{Implications}

The aim of the present study was to examine how innovation control integrates innovations that proceed as a multilevel process. A case study with multiple data sources was conducted to reveal 
the roles of different controls in innovation activities and their complementary roles in innovation control. Our study found that diverse phases of the innovation process have distinct demands with respect to innovation control. The early phase should be supported by indirect control mechanisms, idea development guided with a free and supportive manner; the concept phase agitated by the organisation seeking multiple options and the defined shared goal; and the project development phase should have direct mechanisms with which to control execution and resources (see Figure 14.1). The balancing of freedom and constraint based on agent group construction allows individual, group, and organisational interests to merge with practical measures.

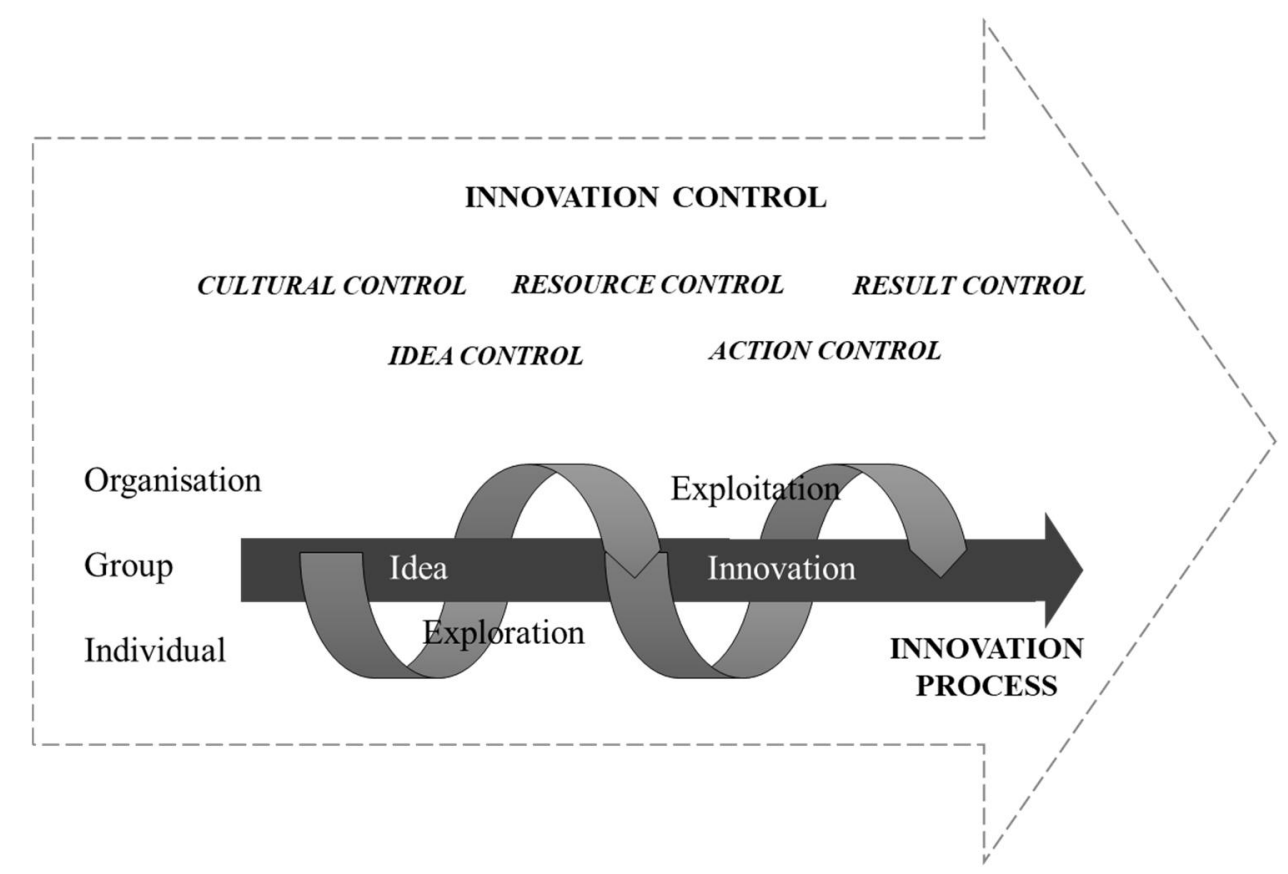

Figure 14.1. Multi-level approach to innovation control

\subsection{Theoretical implications}

From a theoretical perspective, we integrated the lines of research on innovation and management control. The results add to our understanding of controlling and combining innovation resources at individual and group levels to achieve organisational goals. The study findings reveal that different phases of the innovation process have different demands regarding control mechanisms; after all, the purpose of control is not to prevent the dialectic process of innovation. A multiplicity 
of control mechanisms are needed, but these mechanisms require different emphases during different phases of the process. It is easy to put emphasis on only those actions that are visible, which in turn makes it easier to reduce efforts in areas rather than take steps to ensure that they are clearly directed and measured. The organisation should use innovation control to allocate resources in the early innovation process. Companies should also have the capability to locate suitable employees with both knowledge and expertise in addition to somewhat controlling these actions. The challenge is to let the organisation adjust based on the phase of the innovation process and the control mechanisms involved.

Innovation control is not the only means through which the innovation process can be managed, especially in the early phases. The motivation and ability of individuals to dialogue and to engage in constructive debate is also extremely valuable in reaching a joint, actionable result. On the other hand, no organisation's innovation process works without control. In the case company examined in this study, an agent group formed a dialectic platform for dialogue. This platform made possible the dynamic process of combining different levels, including loops that brought complementary ideas back to the individual cognitive level upon the organisation's observation of proceeding innovation.

\subsection{Practical implications}

In terms of practical implication, our results propose that the balance between exploration and exploitation in the innovation process is highly influenced by different control mechanisms. Companies should have a clear vision of the innovation control mechanisms at work in different phases of the innovation process. Innovation control should also focus on the early stages of the innovation process and not only on the concept and implementation phases. Innovation controls have to be flexible and variable to accommodate the demands of rapidly changing operating surroundings.

\subsection{Limitations and future research directions}

The study has some limitations, which can be considered in further research. First, our study builds on one case study within a particular context. Additional case studies are needed to ensure the generalisation of the results. However, several studies have provided empirical arguments 
about the different needs of control in diverse phases of the innovation process (Revellino \& Mouritsen, 2009). The present study confirms these arguments by providing supplementary evidence about the different control mechanisms involved. Our study acknowledges the difficulties of studying dynamic phenomena, such as innovation controls in a rapidly changing business context. We assume that we have managed the challenge well with a combination of various methods of data collection. An opportunity for future research also exists in the study of the managerial role of controls and an innovation agent group as a solution to balance freedom and constraint at multiple levels.

\section{Conclusions}

Rapid changes in business environments and in customer expectations are compelling organisations to rethink and readjust their management controls. These pressures will force firms to focus on how they integrate innovation control at individual, group, and organisation levels. Balancing control between freedom and constraint creates mutual understanding and favourable conditions for the evolution of innovation. Control should not be used to prevent the dialectic process of innovation but should rather support it in a constructive and efficient manner. A multiplicity of control mechanisms is needed, but these mechanisms require different emphases in different phases of the process that support the development of innovation.

\section{References}

Adams, R., Bessant, J., \& Phelps, R. (2006). Innovation management measurement: A review. International Journal of Management Reviews, 8(1), 21-47.

Bledow, R., Frese, M., Anderson, N., Erez, M., \& Farr, J. (2009a). A dialectic perspective on innovation: Conflicting demands, multiple pathways, and ambidexterity. Industrial and Organizational Psychology, 2(3), 305-337.

Bledow, R., Frese, M., Anderson, N., Erez, M., \& Farr, J. (2009b). Extending and refining the dialectic perspective on innovation: There is nothing as practical as a good theory; nothing as theoretical as a good practice. Industrial and Organizational Psychology, 2(3), 363-373. 
Brav, A., Andersson, K., \& Lantz, A. (2009). Group initiative and self-organizational activities in industrial work groups. European Journal of Work and Organizational Psychology, $18(3), 347-377$.

Chebbi, H., Yahiaoui, D., \& Thrassou, A. (2017). Multi-country collaborative innovation in the internationalisation process. International Marketing Review, 34(1), 109-137.

Chenhall, R. H. (2003). Management control systems design within its organizational context: findings from contingency-based research and directions for the future. Accounting, Organizations and Society, 28(2-3), 127-168.

Chesbrough, H. W. (2003). Open innovation: The new imperative for creating and profiting from technology. Boston: Harvard Business School Press.

Chiesa, V., Frattini, F., Lamberti, L., \& Noci, G. (2009). Exploring management control in radical innovation projects. European Journal of Innovation Management, 12(4), 416-443.

Davila, A., Foster, G., \& Oyon, D. (2009). Accounting and control, entrepreneurship and innovation: Venturing into new research opportunities. European Accounting Review, $18(2), 281-311$.

Eisenhardt, K. M. (1989). Building theories from case study research. Academy of Management Review, 14(4), 532-550.

Fjeldstad, Ø. D., Snow, C. C., Miles, R. E., \& Lettl, C. (2012). The architecture of collaboration. Strategic Management Journal, 33(6), 734-750.

Flyvbjerg, B. (2006). Five misunderstandings about case-study research. Qualitative Inquiry, 12(2), 219-245.

Franco, M., \& Bourne, M. (2003). Factors that play a role in "managing through measures". Management Decision, 41(8), 698-710.

Franco-Santos, M., Lucianetti, L., \& Bourne, M. (2012). Contemporary performance measurement systems: A review of their consequences and a framework for research. Management Accounting Research, 23(2), 79-119. 
Haustein, E., Luther, R., \& Schuster, P. (2014). Management control systems in innovation companies: A literature based framework. Journal of Management Control, 24(4), 343382.

Henri, J. F. (2006). Management control systems and strategy: A resource-based perspective. Accounting, Organizations and Society, 31(6), 529-558.

Hutzschenreuther, J. (2009). Management Control in Small and Medium-Sized Enterprises. Wiesbaden: Gabler.

James, L., Guile, D., \& Unwin, L. (2013). Learning and innovation in the knowledge-based economy: beyond clusters and qualifications. Journal of Education and Work, 26(3), 243266.

Janssen, S., Moeller, K., \& Schlaefke, M. (2011). Using performance measures conceptually in innovation control. Journal of Management Control, 22(1), 107.

Kovács, G., \& Spens, K. M. (2005). Abductive reasoning in logistics research. International Journal of Physical Distribution \& Logistics Management, 35(2), 132-144.

Labitzke, G., Svoboda, S., \& Schultz, C. (2014). The role of dedicated innovation functions for innovation process control and performance-an empirical study among hospitals. Creativity and Innovation Management, 23(3), 235-251.

Malmi, T., \& Brown, D. A. (2008). Management control systems as a package—Opportunities, challenges and research directions. Management Accounting Research, 19(4), 287-300.

March, J. G. (1991). Exploration and exploitation in organizational learning. Organization Science, 2(1), 71-87.

Merchant, K. A., \& Van der Stede, W. A. (2007). Management control systems: performance measurement, evaluation and incentives. Harlow, UK: Pearson Education.

Mäkimattila, M. (2014). Organizing for Systemic Innovations-Research on Knowledge, Interaction and Organizational Interdependencies. Doctoral Dissertation, Lappeenranta University of Technology. 
Mäkimattila, M., Melkas, H., \& Uotila, T. (2013). Dynamics of openness in innovation processes - a case study in the Finnish food industry. Knowledge and Process Management, 20(4), 243-255.

Nudurupati, S. S., \& Bititci, U. S. (2005). Implementation and impact of IT-supported performance measurement systems. Production Planning \& Control, 16(2), 152-162.

Prajogo, D. I., \& Ahmed, P. K. (2006). Relationships between innovation stimulus, innovation capacity, and innovation performance. $R \& D$ Management, 36(5), 499-515.

Pålshaugen, Ø. (2009). How to generate knowledge from single case research on innovation?. International Journal of Action Research, 5(3), 231-254.

Revellino, S., \& Mouritsen, J. (2009). The multiplicity of controls and the making of innovation. European Accounting Review, 18(2), 341-369.

Santoro, G., Vrontis, D., Thrassou, A., \& Dezi, L. (2017). The Internet of Things: Building a knowledge management system for open innovation and knowledge management capacity. Technological Forecasting and Social Change.

Saunila, M. (2017). Understanding innovation performance measurement in SMEs. Measuring Business Excellence, 21(1), 1-16.

Saunila, M., Ukko, J., \& Rantanen, H. (2014). Does innovation capability really matter for the profitability of SMEs?. Knowledge and Process Management, 21(2), 134-142.

Schumpeter, J. A. (1934). The Theory of Economic Development. Cambridge, Massachusetts: Harvard University Press.

Simons, R. (2000). Performance measurement and control systems for implementing strategy. Upper Saddle River: Prentice Hall.

Tannenbaum, A. S. (1968). Control in organizations. New York: McGraw-Hill.

Thrassou, A., Vrontis, D., \& Bresciani, S. (2018a). The Agile Innovation Pendulum: Family Business Innovation and the Human, Social, and Marketing Capitals. International Studies of Management \& Organization, 48(1), 88-104. 
Thrassou, A., Vrontis, D., \& Bresciani, S. (2018b). The Agile Innovation Pendulum: A Strategic Marketing Multicultural Model for Family Businesses. International Studies of Management \& Organization, 48(1), 105-120.

Tidd, J., Bessant, J., \& Pavitt, K. (2005). Managing innovation: Integrating technological, market and organizational change. Chichester: John Wiley and Sons Ltd.

Van der Panne, G., Van Beers, C., \& Kleinknecht, A. (2003). Success and failure of innovation: a literature review. International Journal of Innovation Management, 7(03), 309-338.

Voss, C., Tsikriktsis, N., \& Frohlich, M. (2002). Case research in operations management. International Journal of Operations \& Production Management, 22(2), 195-219.

Vrontis, D., Thrassou, A., Chebbi, H., \& Yahiaoui, D. (2012). Transcending innovativeness towards strategic reflexivity. Qualitative Market Research: An International Journal, 15(4), 420-437.

Yin, R. K. (1994). Case study research. Thousand Oaks, USA: Sage Publications.

Ylinen, M., \& Gullkvist, B. (2014). The effects of organic and mechanistic control in exploratory and exploitative innovations. Management Accounting Research, 25(1), 93-112. 